\title{
The availability of credit from the formal financial sector to small and medium enterprises in South Africa
}

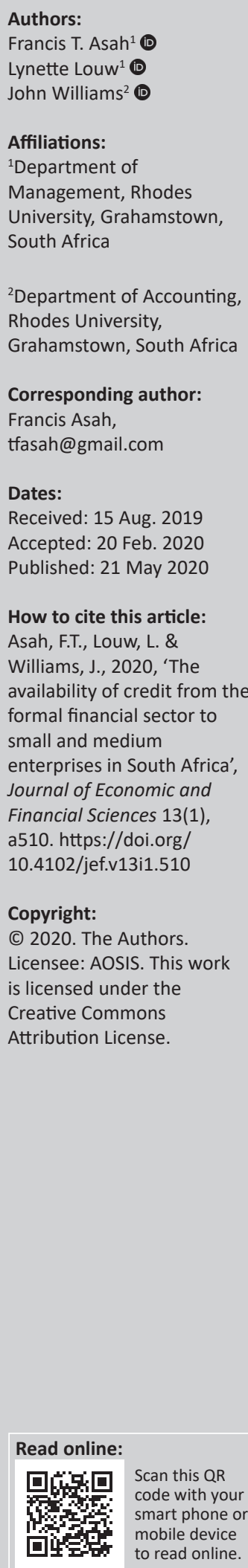

Orientation: Small and medium enterprises (SMEs) in most developing economies depend heavily on credit from the formal financial sector since financial capital from other sources is insufficient for their growth and survival.

Research purpose: Despite SMEs contributing substantially towards sustainable economic development, they have the highest failure rate in South Africa. Thus, the aim of this research is to explore the availability of credit from the formal financial sector to SMEs from a supply side perspective.

Motivation for the study: Research on improving SMEs access to financial capital from the formal financial sector will assist in reducing the failure rate of SMEs and boost economic development in South Africa.

Research approach/design and method: Using an interpretivistic research paradigm, data was collected from credit and business managers from eight of the largest formal financial sector using semi-structured in-depth interviews and analysed using content analysis.

Main findings: The findings revealed that collateral, annual business turnover and audited financial records are the most important factors influencing the formal financial sector to provide credit to SMEs. The lack of investment capital, collateral and financial records are the main challenges faced by the formal financial sector in approving credit to SMEs.

Practical/managerial implications: Implications for government and the private sector in policy development were provided.

Contribution/value-add: This research highlights the most important factors and challenges faced by SMES in accessing credit from the formal financial sector. Using a qualitative research design further contributed, from a methodological perspective, to the literature on the financing of SMEs.

Keywords: availability; credit; formal financial sector; formal financial institutions; SMEs.

\section{Introduction}

Globally, the relative and absolute importance of small and medium enterprises (SMEs) has been well documented in the literature (European Commission 2015; Organisation of Economic Cooperation and Development [OECD] 2017; United Nations 2015; United Nations Development Programme [UNDP] 2016; World Bank 2015). Small and medium enterprises worldwide play a fundamental role in building strong economies through economic development (Global Entrepreneurship Monitor [GEM] 2014; Ikuomola \& Zaaiman 2014:374; Peprah, Mensah \& Akosah 2016:26), poverty alleviation (Fatoki 2014:185; Nieman \& Nieuwenhuizen 2014:13; OECD 2015), employment (GEM 2014; OECD 2015; World Bank 2015) and creating more opportunities for novel small businesses (Garg \& Phayane 2014:60; OECD 2015).

Small and medium enterprises are crucial to the socio-economic development of South Africa, given that SMEs in South Africa constitute $99 \%$ of all businesses, contributing $77 \%$ of all private sector employment and 40\% of the gross domestic product (GDP) (Brijlal 2013; Fatoki 2014:186; GEM 2014; National Planning Commission 2015). Despite the remarkable contribution of SMEs to the economy of South Africa, the failure rate of SMEs (at 75\%) is the highest of all efficiencydriven economies (GEM 2017). Given the high failure rate, international organisations (GEM 2017; IMF 2016; World Bank 2017) affirm that the availability of credit from the formal financial sector to SMEs is reported to be the primary challenge to the survival and performance of SMEs (GEM 2014; Kraemer-Eis et al. 2018; Quartey et al. 2017:19). Therefore, exploring the availability of credit from the formal financial sector to SMEs is fundamental to improve the availability of 
credit from the formal financial sector to SMEs. In the following sections, this article provides the research aim and objectives, a theoretical overview of the relevant theories; describes the research design, approach and method; and presents the findings and discussion. Finally, the conclusions and recommendations are given.

\section{Research aim and objectives}

The aim of this research was to present the findings on the availability of credit from the formal financial sector to SMEs from a supply-side perspective. The supply side refers to providers or suppliers of credit, which, in this case, is the formal financial sector. In other words, they are also referred to as lenders. In addressing the aim of this research, this research explores the following objectives: (1) the factors that impact the willingness of the formal financial sector to provide credit to SMEs, (2) the challenges faced by the formal financial sector in assessing and approving credit to SMEs and (3) how the formal financial sectors perceive investment in SMEs. Hence, the main research questions are as follows: 'what are the factors that impact the willingness of the formal financial sector to provide credit to SMEs in South Africa?', 'what are the challenges faced by the formal financial sector in assessing and approving credit to SMEs in South Africa?' and 'how does the formal financial sector perceive investment in SMEs in South Africa?'

\section{Literature review on the availability of credit from the formal financial sector to small and medium enterprises}

The involvement of the formal financial sector in SMEs is and always has been a fundamental issue of concern amongst policymakers and practitioners in developed and developing countries (such as South Africa), especially at a time of very low or no economic growth and development. According to Mills (2014), finance is the lifeblood of every SME. Bartlett et al. (2014) articulate that the problem of financing SMEs arises from the quality of service they receive from the formal financial sector. According to Bartlett et al. (2014), the terms on which these services are provided are fundamental to the success of SMEs.

Consistent with the views of Bartlett et al. (2014), De la Torre, Peria and Schmukler (2008) argue that inadequate financing of SMEs in developing countries is predominantly influenced by supply-side factors. Small and medium enterprises, on their part, contend that they do not comprehend the reasons behind the high rejection rate of their credit applications, as the formal financial sector most often does not provide feedback as to why their credit applications were not successful (Panda \& Leepsa 2017:77; Ramlee \& Berma 2013:116). Baltar and Icart (2013:204) and Fatoki (2014:186) assert that the formal financial sector in developing countries seems to be uninterested in financing SMEs and such phenomenon is referred to as the 'discrimination hypothesis'.
Padilla-Perez and Ontanon (2013:10) are of the opinion that the formal financial sector is not interested in financing SMEs in developing countries. Theoretical arguments advanced by Padilla-Perez and Ontanon (2013:10) and Panda and Leepsa (2017:76) reveal that information asymmetry according to agency theory (Degryse, De Goeij \& Kappert 2012:436; Padachi, Howorth \& Narasimhan 2012:128), resulting from imperfect market conditions leading to credit rationing, low levels of accountability for credits and market risks, amongst other, are some of the reasons behind the low level of access to credit by SMEs from the formal financial sector.

To support the claim advanced by Baltar and Icart (2013:204) and Fatoki (2014:186) that the formal financial sector in developing countries seems to be uninterested in financing SMEs, contemporary scholars (Adzido \& Azila-Gbettor 2014:197; Ramlee \& Berma 2013:118; Richard \& Mori 2012:218) argue that some of the reasons why the formal financial sector does not lend to SMEs (supply side) in developing countries include cost-effectiveness of credits to SMEs, imperfections involved in SME lending, opaqueness of borrowers, high transaction costs, information economics arising from imperfections involved in SME lending and lending technologies to assess credit applications. However, Makomeke, Makomeke and Chitura (2016:66) point out that assessing, evaluating and granting credit to SMEs remain at the heart of the decision-making process of credit and business managers. One of the challenges that formal financial institutions experience in their decision-making process relates to assessing non-performing credit because of weak credit analysis. Thus, the rejection rate of applications is higher than it should be.

Even though Ebrahim et al. (2016:59) state that the primary purpose of formal financial institutions is not only to accept deposits but also to provide financial services (such as credit facilities), the authors caution that formal financial institutions inevitably expose themselves to a number of risks while performing their function of granting credit facilities. These risks, caused by the unpredictable, unstable economic and political atmosphere, include credit risk, liquidity risk, operational risk, capital risk, market risk, investment risk, foreign exchange risk and interest rate risk, along with other risks, which may possibly threaten the survival and success of different financial institutions (Ebrahim et al. 2016:60). Rahman, Zheng and Ashraf (2015:96) argue that credit risk is by far the most threatening risk faced by most formal financial institutions and their success greatly depends on how well this risk is managed. Konovalova, Kristovska and Kudinska (2016:92) define credit risk as a risk of borrower default, which may arise as a result of the possibility that formal financial institutions' borrowers or counterparts will fail to meet their obligations in accordance with agreed terms.

On top of credit risk, Baby and Joseph (2016:2), Haven (2015:3758), Kwaning, Nyantakyi and Kyereh (2015:20) and World Investment Report (2017) indicate that formal financial institutions in developing countries, such as South Africa, 
face a number of challenges that prevent them from pulling financial resources together and lending to SMEs. These challenges, according to Baby and Joseph (2016:2), account for the large credit financing gap between supply capacities of formal financial institutions and the demanding needs of SMEs. These challenges include the absence of a proper legal and regulatory framework for dealing with default cases (Baby \& Joseph 2016:2; Haven 2015:3758), high transaction costs involved in doing business with SMEs (Kapunda 2015), absence of credit rating agencies (Mutoko 2015:3) and lending technologies (Kwaning et al. 2015:21).

Despite the challenges faced by formal financial institutions in lending to SMEs, Siddik, Kabiraj and Joghee (2017:3) advocate that formal financial institutions are reluctant to lend to SMEs because the use of credit can negatively impact the performance of SMEs during difficult economic conditions. The current state of the South African economy (an economy characterised by high interest rates) suggests that it will be difficult for SMEs to have a positive leverage, especially with the current economic downturn. A positive leverage occurs when SMEs operate under favourable conditions, when sales and profits margins are high and SMEs are able to generate a good return on assets (Pai \& Hiremath 2013:418). During difficult times, cost of lending becomes high and SMEs experience low sales and profit margins, thus leading to negative leverage. In accordance with the view of Siddik et al. (2017:3), the pecking order theory emphasises that SMEs should rely more on internal sources of finance (retained earnings) before external borrowing to finance their growth and survival (Adzido \& Azila-Gbettor 2014:198; Menike 2015:57). The static trade-off theory, on the other hand, advocates that SMEs should use the tax advantage of debt and go for more debt. Despite the tax advantage of debt to SMEs, the formal financial institutions would rather minimise lending risk by not lending to SMEs as they are not certain if SMEs can repay the principal and interest on the principal during tough economic times as the current state of the South African economy.

\section{Research design, approach and method}

This qualitative research is located within the interpretivistic research paradigm that is grounded in the epistemological tradition of constructivism and pragmatism (Collis \& Hussey 2014:43). In the pragmatic research approach, the dictate of science is not only to find truth or reality, but also to facilitate human problem solving (Bezzina \& Saunders 2014:31). This research is therefore based on the premise that multiple realities and interpretations exist (Ihuah \& Eaton 2013:936; Narh 2013). To reduce human subjectivity in the multiple realities researcher applied a self-reflexive attitude to achieve qualitative, in-depth interpretations of the text of lived experiences (Bambale 2014:866).

This research focused on eight largest formal financial institutions responsible for about $91 \%$ of all assets and about
$85 \%$ of all liabilities in the commercial banking sector in South Africa (Banking Association of South Africa 2018), which employ about 106 credit and business managers in the Gauteng province. Purposive sampling was used in selecting the participants from the eight selected formal financial institutions in Gauteng, often referred to as being the head office bank. The head office banks have all the policies and guideline documents in place to guide the lending decisions of the credit and business managers at the branch level. The head office banks also have more knowledge and experience in lending decision. As such, the purposive sampling focused on credit and business managers at the head office level. Interviewing a credit and a business manager at the head office would yield more insights than interviewing such a manager at the branch office. Hence, taking into consideration regulations and guidelines governing credit lending in each formal financial institution, interviewing more than one credit and business manager from a single institution would normally lead to data saturation. A credit manager and a business manager were interviewed from each institution. Therefore, a total of eight credit managers and eight business managers voluntarily accepted to be interviewed.

In the context of research ethical clearance, written permission letters were obtained from each institution to conduct research and written consent form was signed by each participant. The participants were assured of anonymity, confidentiality and the freedom to withdraw from the research at any time if they wished so. Of the participants, seven $(44 \%)$ were women (three credit managers and four business managers), while nine (56\%) were men (five credit managers and four business managers). All participants were South Africans.

\section{Data collection}

Data for this research were collected by means of face-to-face in-depth interviews (conducted in English) that lasted for 45-60 min. The interview guide, aligned with the research questions posed, theory and literature review, was divided into five sections. The first section was the demographical characteristics of participants, the second section 'Research aim and objectives' focused on credit assessment and evaluation, the third section 'Literature review on the availability of credit from the formal financial sector to small and medium enterprises' focused on the challenges in lending to SMEs, the fourth section 'Research design, approach and method' focused on formal financial institutions' lending attitude and the fifth section 'Research findings' focused on improving access to credit to SME. Examples of the interview questions are as follows: 'with respect to the major investment areas you have highlighted, what decision-making criteria do you consider when lending to start-up, established and expanding SMEs?', 'given the lending criteria put in place by your institution, to what extent do SMEs comply with these criteria?', 'what are the challenges your institution is facing in trying to address the problem of compliance with lending?', and 'for the length of time you have worked with this institution, do you believe 
that your institution is committed to lending to SMEs? If yes, please explain how'.

Data collected through interviews were transcribed and were stored according to the ethical guidelines. Data were also retransferred to the participants representing the different formal financial institutions for the purpose of enhancing credibility of the findings.

\section{Data analysis}

Data analysis was based on the five-step process of content analysis described by Terre Blanche, Durrheim and Kelly (2006:322-326), namely, familiarisation and immersion, inducing themes, coding, elaboration, interpretation and checking.

\section{Qualitative research criteria and limitations}

The data analysis is evaluated against the qualitative 'quality research criteria' (Collis \& Hussey 2014), such as credibility, transferability, dependability and confirmability. A transparent description of the analysis, supported by a sound research design, contributed towards the 'quality' of the research findings (Collis \& Hussey 2014). With regard to transferability of the research findings, this study is limited to the head offices of the eight selected formal financial institutions located in the Gauteng province, South Africa. Despite the in-depth insights obtained from the participants, the findings of this research are limited to the eight formal financial institutions selected for this research. Therefore, the findings are not generalisable to other formal financial institutions operating in South Africa. However, the findings might be useful to other formal financial institutions that were not part of this research.

\section{Research findings}

The biographical information shown in Table 1 includes the participants gender, age range, ethnic group (EG), current position $(\mathrm{CP})$, duration of current position $(\mathrm{DCP})$, previous position (PP), duration of previous position (DPP), highest qualification $(\mathrm{HQ})$ and previous employer $(\mathrm{PE})$. Interviews were conducted with eight credit $\left(\mathrm{C}_{1}-\mathrm{C}_{8}\right)$ and eight business managers $\left(\mathrm{M}_{1}-\mathrm{M}_{8}\right)$, as shown in Table 1.

The findings, aligned with addressing the research questions, are presented in the following sections.

\section{Factors that impact the willingness of the formal financial sector to provide credit to small and medium enterprises}

Table 2 provides a tabular summary of the perspectives of participants on the factors that impact the willingness of the formal financial sector to provide credit to SMEs.

In Table 2, the numbers of participants are indicated in the left column and the frequency of citations of a particular factor (middle column) is given in the right column. This means that, for example, in terms of collateral, while all the participants regarded this factor as being important, the importance was further enhanced by the frequencies $(n=32)$ of mention by these participants. The level of importance of each factor is thus determined by the frequency of mention rather than the number of participants. Therefore, the factors that impact the willingness of the formal financial sector to provide credit to SMEs, from the most to the least important, are collateral, annual business turnover, audited financial records, relationship with the bank, credit profile, nature of the business, economic climate, ethics, nationality, government policy, management team, valid identity document or permit document, equity contribution, entrepreneurship education, quality of product and business intelligence.

Collateral security (as shown in Table 2) is the most important $(n=32)$ requirement considered by the formal financial sector in granting credit to SMEs. Participants (from the formal financial sector) indicated that they generally consider

TABLE 1: Biographical data.

\begin{tabular}{|c|c|c|c|c|c|c|c|c|c|}
\hline Code & Gender & $\begin{array}{l}\text { Age range } \\
\text { (years) }\end{array}$ & Ethnic group & $\mathrm{CP} \uparrow$ & DCP & $P P \dagger$ & DPP & $\mathrm{HQ}$ & $\mathrm{PE}$ \\
\hline $\mathrm{C}_{1}$ & Male & $35-40$ & Black & $\mathrm{CM}$ & 5 years & RM & 7 years & Degree & Another employer \\
\hline $\mathrm{C}_{2}$ & Female & $30-34$ & Black & $\mathrm{CM}$ & 3 years & RM & 6 years & Diploma & Same employer \\
\hline $\mathrm{C}_{3}$ & Male & $41-45$ & White & $\mathrm{CM}$ & 7 years & RM & 4 years & Degree & Same employer \\
\hline $\mathrm{C}_{4}$ & Male & $35-40$ & Black & $\mathrm{CM}$ & 6 years & CA & 5 years & Degree & Another employer \\
\hline $\mathrm{C}_{5}$ & Female & $35-40$ & Black & $\mathrm{CM}$ & 6 years & $\mathrm{CM}$ & 7 years & Adv. Diploma & Same employer \\
\hline $\mathrm{C}_{6}$ & Male & $41-45$ & Black & $\mathrm{CM}$ & 4 years & $\mathrm{CM}$ & 7 years & Degree & Same employer \\
\hline $\mathrm{C}_{7}$ & Female & $35-40$ & Black & $\mathrm{CM}$ & 6 years & $\mathrm{BM}$ & 8 years & Degree & Another employer \\
\hline $\mathrm{C}_{8}$ & Male & $35-40$ & Black & $\mathrm{CM}$ & 6 years & $\mathrm{CM}$ & 4 years & Degree & Same employer \\
\hline$M_{1}$ & Female & $35-40$ & Black & $\mathrm{BM}$ & 7 years & CA & 5 years & Degree & Another employer \\
\hline $\mathrm{M}_{2}$ & Female & $35-40$ & White & $\mathrm{BM}$ & 4 years & RM & 7 years & Degree & Same employer \\
\hline$M_{3}$ & Female & $30-34$ & Indian & $\mathrm{BM}$ & 5 years & RM & 6 years & Post G Degree & Same employer \\
\hline $\mathrm{M}_{4}$ & Male & $50-55$ & White & $\mathrm{BM}$ & 11 years & $\mathrm{BM}$ & 5 years & Matric (NSC) & Same employer \\
\hline$M_{5}$ & Male & $41-45$ & White & $\mathrm{BM}$ & 5 years & $\mathrm{BM}$ & 5 years & Degree & Same employer \\
\hline$M_{6}$ & Female & $41-45$ & Black & $\mathrm{BM}$ & 8 years & RM & 5 years & Adv. Diploma & Same employer \\
\hline$M_{7}$ & Male & $35-40$ & Black & BM & 6 years & BM & 4 years & Degree & Same employer \\
\hline $\mathrm{M}_{8}$ & Male & $35-40$ & Black & $\mathrm{BM}$ & 4 years & CA & 6 years & Degree & Another employer \\
\hline
\end{tabular}

$\mathrm{CP}$, current position; $\mathrm{DCP}$, duration of current position; $\mathrm{PP}$, previous position; $\mathrm{DCP}$, duration of previous position; $\mathrm{HQ}$, highest qualification; $\mathrm{PE}$, previous employer.

$\dagger, \mathrm{CM}$, credit manager; $\mathrm{BM}$, business manager; $\mathrm{CA}$, credit analyst; RM, relationship manager. 
TABLE 2: Perspectives of participants regarding the factors that impact the willingness of the formal financial sector to provide credit to small and medium enterprises.

\begin{tabular}{|c|c|c|}
\hline Participants & $\begin{array}{l}\text { Factors that influence the provision of credit to small and } \\
\text { medium enterprises }\end{array}$ & $\begin{array}{l}\text { Frequencies } \\
\qquad(n)\end{array}$ \\
\hline$C_{1}, C_{2}, C_{3}, C_{4}, C_{5}, C_{6}, C_{7}, C_{8}, M_{1}, M_{2}, M_{3}, M_{4}, M_{5}, M_{6}, M_{7}, M_{8}$ & Collateral & 32 \\
\hline$C_{1}, C_{2}, C_{4}, C_{5}, C_{7}, C_{8}, M_{1}, M_{2}, M_{4}, M_{5}, M_{7}, M_{8}$ & Annual business turnover & 24 \\
\hline$C_{1}, C_{2}, C_{5}, C_{6}, C_{8}, M_{1}, M_{2}, M_{5}, M_{6}, M_{8}$ & Audited financial records & 16 \\
\hline$C_{1}, C_{2}, C_{4}, C_{5}, C_{6}, C_{8}, M_{1}, M_{2}, M_{5}$ & Relationship with the bank & 13 \\
\hline$C_{5}, C_{6}, C_{7}, C_{8}, M_{5}, M_{6}, M_{7}, M_{8}$ & Credit profile & 10 \\
\hline$C_{4}, C_{7}, C_{8}, M_{4}, M_{7}, M_{8}$ & Nature of the business & 10 \\
\hline$C_{6}, C_{7}, C_{8}, M_{6}, M_{7}, M_{8}$ & Economic climate & 9 \\
\hline$C_{1}, C_{2}, C_{5}, C_{8}, M_{1}, M_{2}, M_{4}, M_{6}$ & Ethics & 8 \\
\hline$C_{6}, C_{7}, C_{8}, M_{6}, M_{7}, M_{8}$ & Nationality & 6 \\
\hline$C_{5^{\prime}}, C_{7}, C_{8^{\prime}}, M_{5^{\prime}}, M_{7}, M_{8}$ & Government policy & 6 \\
\hline$C_{4}, C_{7}, M_{5}, M_{7}$ & Management team & 5 \\
\hline$C_{1}, C_{2}, C_{3}, C_{7}, M_{1}, M_{2}, M_{3}, M_{7}$ & Valid identity document or permit document & 4 \\
\hline$C_{2}, C_{7}, M_{3}$ & Equity contribution & 3 \\
\hline $\mathrm{C}_{4}$ & Quality of product & 1 \\
\hline$\underline{M_{3}}$ & Business intelligence & 1 \\
\hline
\end{tabular}

granting credit to SMEs that have collateral in the form of an asset (land or property), investment account, contract letter, investment policy and surety (which is worth the size of the credit). One of the participants $\left(C_{1}\right)$ stated that:

'We need some form of collateral before we do the lending. So, it depends. Usually, it would be either a property (such as a house or productive land infrastructure) or an investment account has to be opened with us. So, it would be sort of like an investment with a certain amount. So, they are basically securing the credit with this investment. This investment will not be cashed before the loan is paid up or they will not have access to the investment until we basically get to know whatever they are owing onto their loan'.

From the participants' perspectives, holding collateral is a way of protecting the institutions' interest as owners of SMEs would be bound to give their all to ensure the repayment of the credit. As for the annual business turnover $(n=24)$, it helps formal financial institutions to assess if the business will be able to pay back the credit, as one of the participants $\left(\mathrm{M}_{4}\right)$ stated that:

'We look at the project and check what is their annual turnover and that will they be able to get out of the business after we finance it and we would also ensure that the loss will not be detrimental to our business as well. So, we look at the annual turnover of the business for the year and if we are not satisfied with the annual turnover, it means the business is struggling and we will likely reject such application. How can you pay your debt if you are struggling to sell your products?'

A well-maintained and audited financial records $(n=16)$ reveal information about the financial performance of the business, as one of the participants $\left(\mathrm{C}_{2}\right)$ noted:

'To us, audited financials are very important. If not available then a management account, if not available then bank statements. I think audited financial statements are good enough even though a lot of credit managers do not really like them. Audited financial statements are evidence of the financial strength of the business, to show that the client can pay or not'.
The relationship between owners of SMEs and the formal financial institutions $(n=13)$ helps formal financial institutions to know their client and their business, as highlighted by one of the participants $\left(\mathrm{M}_{2}\right)$ :

'The relationship between client and manager is very important to us because it gives us the opportunity to know our client and their businesses. Because when you know your clients and their businesses, you can easily tell if the business is a good business that has growth prospect. But if the business is struggling, then we can easily tell if the owner will be able to pay back the loan or not. So the relationship is very important to us'.

The above-mentioned four factors (collateral, annual business turnover, audited financial records and relationship with the bank) with frequencies greater than 10 are the most important from the formal financial institutions' point of view. These findings suggest that SME owners who meet the requirements of these factors are most certainly likely to access credit from the formal financial institutions. Credit profile $(n=10)$ and nature of the business $(n=10)$ are also important factors in enhancing the success of an application. The unstable economic climate $(n=9)$ has made formal financial institutions to become more risk-averse and are not interested in funding businesses that will tarnish (ethics, $n=8$ ) the institutions' name. The issue of information asymmetry in SMEs financing has made some formal financial institutions not interested in funding immigrant businesses (nationality, $n=6$ ). Government policy $(n=6)$ on lending as stipulated in the Credit Agreement Act is also limiting formal financial institutions from lending more to SMEs, as noted by one of the participants $\left(M_{7}\right)$ :

'So, there is a different criterion that is applied to different people. So, you have a natural person, which is an immigrant from another country and if they would like to own property in South Africa, they would have to put down a $50 \%$ deposit, which is governed by the Reserve Bank policy. So, again, we have to then look to the Reserve Bank policy. If a person is bringing in a company from overseas, we would have to verify everything before we could look at financing but there are a lot of things that we are still going to be governed by the Reserve Bank so, whether it is for imports or exports, there are different criteria'. 
Other least important factors such as management team $(n=5)$ is fundamental in the implementation of good governance, a valid ID (identity document) or permit document $(n=4)$ is essential for verification purposes for immigrant entrepreneurs and equity contribution $(n=3)$ of SME owners is a show of faith that SME owners are investment ready. Entrepreneurship education $(n=1)$ gives SME owners the knowledge to write proper business plans, the quality of the product $(n=1)$ offered by SME owners should be appealing to customers and business intelligence $(n=1)$ help SME owners to have that business insights of their business (manage a business successfully, make informed decisions and understand the business industry).

\section{Challenges faced by the formal financial sector in assessing and approving applications for credit by small and medium enterprises}

Table 3 provides a summary of the perspectives of participants on the challenges faced by the formal financial sector in assessing and approving applications for credit by SMEs.

Lack of investment capital from SME owners $(n=26)$ is the most serious challenge faced by formal financial institutions when considering providing credit to SMEs. Contemporary literature iterates that the main reason why formal financial institutions are not interested in investing in SMEs is because SME owners are not investment ready as noted by one of the participants $\left(\mathrm{M}_{5}\right)$ :
'.... When someone comes to the bank for credit and when you ask the persons how much do they have to invest in the business idea, they tell you that nothing and that is why we are coming to the bank so that the bank can help. Let me tell you this, it is a standard practice that we only give $50 \%$ of what the equity of a business is. So, in other words, if you put R50 000, we look at R50 000. However, we have got some instances with the DTI (Department of Trade and Industry) that they will also give some guarantee from their side to be able to take it up to $80 \%$. So, one needs to understand what will actually happen in such situation like that. If I put $80 \%$ into a business, say R80 000 out of a total of a hundred thousand, and you put in R20 000, technically, you owe me R80 000. You have put in R20 000. So, you are R60 000 short. Therefore, you are technically insolvent and the law says that we are not supposed to lend to an insolvent or technically insolvent business. That is the reason why it becomes very difficult to just give out loans when the clients themselves do not have anything to motivate that they are serious in their business'.

Therefore, SME owners will find it very difficult to access credit from the formal financial institutions in the absence of equity contribution of the owners. On the other hand, lack of collateral $(n=20)$ is the second most serious challenge faced by formal financial institutions when considering lending to SMEs. Holding collateral is a way of protecting the institutions' interest, the absence of collateral, according to the participants, increases the credit risk and formal financial institutions are not willing to take on such risk. Hence, such clients without collateral are denied credit as noted by one of the participants $\left(\mathrm{C}_{3}\right)$ :

'Holding collateral is very important to us because situation may occur that the credit application of my client is denied because the client does not qualify for such amount of credit. For example, your business and asset which you offer as collateral is worth R5 million and you apply for a loan of R5 million. We will never give you such amount of credit because the risk is too high and your collateral cannot cover the loan in case you default. So, yeah. In that case, the credit application will be denied'.

Lack of proper financial records is another serious challenge faced by formal financial institutions when considering lending to SMEs. According to some of the participants, formal financial institutions use financial records to determine the present and predict the future performance of SMEs as captured in the excerpt highlighted by $\mathrm{C}_{4}$ :

'Most of the time, it is a hustle to get the financial record documents, especially let us say it is a new business or a client that deals with services and then they do not provide us with any financial records to control, then, we will turn our attention to the account they have with us. So, we will require a four years management account. Another thing I will like to tell you is that some clients do not take time to keep their financials in order and that makes our job very difficult. Some want to do their financial only when they are preparing to apply for a loan and when we ask about their past financial record, they tell us they do not have it'.

The management skills $(n=13)$ of SME owners are also a very serious challenge faced by formal financial institutions when assessing their credit application. According to the participants, poor management skills of SME owners reduce the legitimacy of the credit application as captured in the excerpt from $\mathrm{C}_{7}$ :

'In the past year, I have realised some clients use business funds to purchase personal asset that does not bring any revenue to the business. How can you use money that you use in running your business to pay for a private car and you then apply for a loan that you want to settle some business expense? That is a wrong decision. You cannot even use the car as a security to apply for a loan. This is the kind of decision some of these clients do. So, when this kind of client applies for a loan, we look at the cash

TABLE 3: Perspectives of participants with regard to challenges faced by formal financial institutions in providing credit to small and medium enterprises.

\begin{tabular}{|c|c|c|}
\hline Interviewee & Perspectives of business and credit managers & Frequencies $(n)$ \\
\hline$C_{1}, C_{2^{\prime}}, C_{3}, C_{4}, C_{5}, C_{6}, C_{7}, C_{8}, M_{1}, M_{2^{\prime}}, M_{3^{\prime}}, M_{4}, M_{5}, M_{6}, M_{7}, M_{8}$ & Lack of investment capital & 26 \\
\hline$C_{1}, C_{2}, C_{3}, C_{4^{\prime}}, C_{6}, C_{8}, M_{1}, M_{2}, M_{3}, M_{4^{\prime}}, M_{6}, M_{8}$ & Lack of collateral & 20 \\
\hline$C_{1}, C_{2}, C_{3}, C_{4}, C_{6}, C_{7}, C_{8}, M_{1}, M_{2}, M_{3}, M_{4}, M_{8}$ & Lack of proper financial records & 18 \\
\hline$C_{1}, C_{2}, C_{3}, C_{5}, C_{6}, C_{7}, C_{8}, M_{1}, M_{2}, M_{5}, M_{6}$ & Poor managerial skills & 13 \\
\hline$C_{3}, C_{6}, C_{7}, M_{5}, M_{7}, M_{8}$ & Poor business plan & 7 \\
\hline$C_{1}, C_{4}, C_{7}, M_{3}, M_{6}, M_{7}$ & Lack of industrial knowledge & 6 \\
\hline$C_{2}, M_{1}, M_{3}$ & Poor legal and credit laws & 3 \\
\hline
\end{tabular}


flows from the financials of the business in the past months, say, six to twelve months and then try to come out with projections over the coming months. So, if it is a business that generates enough revenue, we will look at the amount of the loan and the estimated time the clients request to pay back the loan. If I am satisfied with my calculations, and the amount requested by the client, then I will process the credit application'.

Writing a good business plan $(n=7)$ is a problem with SME owners as some of the participants noted that poor business plans are another challenge faced by formal financial institutions when considering lending to SMEs. According to the participants, the business plan is an important document that sells the vision of the owners of the business to formal financial institutions. The participants explained that a poor business plan did not convince the formal financial institution of the future prospect of the business applying for credit. As a result, the credit application of SME owners with poor business plans finds it difficult to access credit from the formal financial institutions. Lack of industry knowledge ( $n=$ 6 ) and poor legal and credit laws $(n=3)$ are the other challenges faced by formal financial institutions when considering lending to SMEs. According to the participants, SME owners with little knowledge about the industry in which they operate will find it difficult to compete with other businesses in that industry. Business as such might find it difficult to generate enough sales to repay credit expenses. On the other hand, the fact that legal and credit laws are not enforceable worsens the credit rationing to SMEs, as one of the participants $\left(\mathrm{M}_{3}\right)$ noted:

'... At first, we gave some business loans without holding certain things. After some time, I mean months, when we realised that they are not paying the monthly instalments, we went to the business premise to check what was happening only to find out that the business is no longer operating there. We know the persons we gave the loan to and we see some of them most of the time. But we cannot do them anything. We took some to court and when the court asked them to sign a document that they will pay back the loan, they signed but they keep on saying they do not have money because the business took all their money. We expect the court to do something to force these people to pay but nothing is happening. But some are paying. Is just that the way they are paying is not encouraging'.

\section{Formal financial sectors' perceptions of providing credit to small and medium enterprises}

Notwithstanding the challenges faced by formal financial institutions with regard to lending to SMEs, formal financial institutions are still committed to assist such enterprises, as one of the participants $\left(\mathrm{C}_{3}\right)$ stated:

'We are so committed and confident in lending to SMEs because even top management recommends that we do not decline many credit applications because when we give credit to businesses, they will be able to hire more people from the locations. I can tell you now we have about 3869 business accounts in this branch office and as a senior credit manager, I have to handle about 2000 of these accounts. It is my responsibility to make sure that my clients have their credit when they request for it because I make sure that I communicate with the clients on issues concerning their accounts and I also help them to put their credit applications in order so that they can have their credit. Another thing that we ask from our clients when we approve you a loan sometimes is that, can we also look after your payroll? So, we are saying, if you have got for example, 100 employees, since you are banking with us, we will want all your employees to also open their salary accounts with us. So, in other words, it will also be a business for us and this also helps us to know how the business is doing and it can also help you as a business to make your credit application worthy'.

Contrary to the literature that the credit application of most SMEs is rejected by formal financial institutions, most participants were in agreement that about $70 \%$, on average, of all applications for credit are approved as captured in the excerpt from one of the participants $\left(\mathrm{C}_{2}\right)$ :

'I can tell you that about $80 \%$ of all the credit applications I have processed were approved. That is to say, for every twenty application I have processed this year, at least, 17 are approved and the three that were rejected had a little problem to do with their collateral but they have re-applied last week and I am sure they will get their credit this time. We just need to have our normal meetings as credit managers to review all those that have applied for credit this month. But like I said, the credit applications must contain all the relevant documents before I can process the application'.

\section{Discussion}

According to the findings highlighted in section 'Factors that impact the willingness of the formal financial sector to provide credit to small and medium enterprises', collateral, annual business turnover, audited financial records, relationship with the bank, credit profile and nature of the business were the most important factors that impact the willingness of formal financial sector to provide credit to SMEs. According to Quartey et al. (2017:19), a lending institution is more confident in providing credit to a business where the there is sufficient collateral and the owner's contribution is extensive. Owners in such businesses are likely to be averse to risky investments, thus reducing moral hazard for the lending institution. In addition, collateral can be repossessed by the creditor in case of default, thus enhancing creditor protection (Stoop \& Churr 2013:515). With respect to annual turnover and audited financials, Taneli and Ohl (2014:586) emphasised that one of the principal measures of the capacity of SMEs to effect repayment of credits is business information (annual business turnover, audited financial records, credit profile and nature of the business). Therefore, SME owners who are able to produce complete business information about their business enhance their chances of credit approval from formal financial institutions and other lenders. In addition, in an economic environment characterised by high unemployment, ethical practice establishes trust and the relationship between formal financial institutions and SMEs helps to reduce information asymmetry (Nieman \& Nieuwenhuizen 2014:31). With trust and good relationships between formal financial institutions and SMEs, SMEs with a good credit profile (i.e. those that have not defaulted credit payment in the past) stand a good chance of accessing more credit (Liang et al. 2017:138). 
Irrespective of trust and information asymmetry, credit rationing at times is caused by economic environment characterised by low growth prospect and credit policy that is seldom enforceable. For example, in an economic environment where immigrant entrepreneurship is not appreciated, entrepreneurship education is not encouraged (Nieman \& Nieuwenhuizen 2014:31), business intelligence is not appreciated (Curraj 2017:150) and entrepreneurship is not regarded as a career choice (Testa \& Frascheri 2015:12), the level of entrepreneurship activities is bound to be low. Such an economic environment discourages formal financial institutions from providing credit to SMEs (Nieman \& Nieuwenhuizen 2014:31; Quartey et al. 2017:19; Testa \& Frascheri 2015:13).

With respect to the findings in the section 'Challenges faced by the formal financial sector in assessing and approving applications for credit by small and medium enterprises', contemporary studies (Baby \& Joseph 2016:2; Haven 2015:3758; Kwaning et al. 2015:20) posit that lending to SME owners with little or no equity contribution is more risky than lending to large companies by all objective measures. As a result, formal financial institutions have resorted to holding collateral as a means to reduce the amount of risk in lending to SMEs. When considering the three theories together (the static trade-off theory, the agency theory and the pecking order theory), Frelinghaus, Mostert and Firer (2005:13) highlight that the theories are in agreement with the fact that the inadequacy of owners' contribution and the lack of retained earnings for most SMEs are responsible for their poor performance. According to Cenni et al. (2015:250), poor financial records of SMEs put formal financial institutions in a difficult position to provide credit to SMEs, given that formal financial institutions use financial records of SMEs to evaluate their credit worthiness. In addition to poor financial records of SMEs, Adzido and Azila-Gbettor (2014:197) argue that most SMEs find it difficult to access credit from formal financial institutions because of the poor management skills and poor business plans of the owners or managers. Adzido and Azila-Gbettor (2014:197) concluded that lack of management skills and the poor business plan of owners or managers of SMEs decrease their legitimacy, thus increasing credit rationing amongst SMEs. Lack of industry knowledge implies that SME owners cannot make strategic decisions (Kwaning et al. 2015:20) and the efficiency of the legal system must be improved to protect lenders in case of credit default by SMEs to improve the availability of credit from the formal financial institutions (Kostov, Arun \& Annim 2015:37). Despite the poor legal and credit laws, the notion that the formal financial sector is not interested in providing credit to SMEs, according to literature, is not true based on the findings in section 'Formal financial sectors' perceptions of providing credit to small and medium enterprise'.

\section{Conclusion and recommendations for theory and practical implications}

The findings of this research revealed that although formal financial institutions are risk-averse, they acknowledge investing in SMEs to be beneficial to their business. Therefore, formal financial institutions are very interested to provide credit to SME owners who can contribute a portion of the starting capital or provide some sort of collateral that is worth the credit. This implies that formal financial institutions always want to mitigate the risk of granting credit to SMEs. The findings further revealed that there are factors (as highlighted in Table 2) that impact non-availability of credit from the formal financial institutions to SMEs. Based on the findings in this research and the literature review, the following recommendations are made with the aim of enhancing the financing of SMEs.

There is need for government and the formal financial sector to work together to put in place strategies (by developing different lending technologies that combine different sources of information about a borrower, screening and underwriting procedures, structure of a loan contract and monitoring mechanisms) aimed at developing long-term capital market for novel and established SMEs. Even though the static tradeoff theory suggests that SMEs should use more credit if available, other policies aimed at encouraging SMEs to access public equity capital could be developed by subsidising floatation cost. Such policies should motivate SMEs to restructure their financing so as to rely on less debt, particularly short-term debt, thus improving their liquidity.

Another strategy that government can use to motivate the formal financial sector to design special credit schemes for SMEs is by extending the broad based black economic empowerment point's model in lending. Introducing this model in lending, formal financial institutions are able to gain points when they support local owner SMEs. The points accumulated by each formal financial institution each year can be used for enterprise tax rebates. In addition, government, in collaboration with the formal financial sector, should consider developing special funding packages for promoting SMEs. These policy directions would not only help improve access by SMEs to long-term finance but also encourage potential individuals to become entrepreneurs, which will, in turn, boost the level of entrepreneurship and reduce unemployment and poverty.

To further motivate and expand lending to SMEs, formal financial institutions also need to develop alternatives to property as collateral to secure long-term credits. Personal guarantees, sales contracts and lien on equipment financed could be explored. Formal financial institutions could also work in partnership with informal finance lenders in granting credit to SMEs. In such a partnership arrangement, formal financial institutions could take advantage of the privileged information held by informal finance lenders about small businesses and the relatively low cost of frequent small transactions. In addition, formal financial institutions are encouraged to set up departments that would focus solely on granting credits to SMEs. The creation of such departments will help speed up the credit assessment and approval process, and feedback on credit application will be provided quicker. 
Another viable and novel practice that could help reduce the demand of formal financial institutions for collateral is the introduction of the 'competency-as-collateral' scheme. This scheme has been tested in India and is currently gaining popularity because of its significant success rate (Kumari \& Sita 2010). This scheme integrates measures of management competency with the conventional credit risk assessment criteria set by formal financial institutions. Customised evaluation systems built on the basis of this platform could assist SMEs that do not qualify for credit under the conventional criteria to become eligible by allowing them to show their management competence as part of their collateral. The only difficulty with such an approach (using competencyas-collateral) is that owners of SMEs must be highly educated to be able to pitch their idea and business plans to convince formal financial institutions that they are aware of their market and business industry, and thus the importance of entrepreneurship education and business intelligence.

Furthermore, the credit criteria set by formal financial institutions should be more flexible to enable more SMEs to qualify for access to such finances, as noted by one of the participants $\left(\mathrm{M}_{1}\right)$ :

'... When you empower a client, you do not only empower one person but you empower more people around your community because the person you fund will hire other people in the community and the people will come open an account with us. So, it is a win-win situation'.

Thus, routing these facilities through formal financial institutions should be reconsidered.

\section{Acknowledgements}

The participants from the different formal financial institutions involved in the study have made this research possible.

\section{Competing interests}

The authors declare that they have no financial or personal relationships that may have inappropriately influenced them in writing this article.

\section{Authors' contributions}

F.T.A. contributed to the abstract, literature review, data collection and analysis. L.L. contributed to the summary and conclusion sections. J.P. contributed to proofreading of the article.

\section{Ethical consideration}

Research involving humans is essential for the improvement of knowledge in the sphere of humans and the society at large. Protecting the rights and dignity of humans involved in research is thus of utmost importance. This study conformed to all ethical requirements as specified by the university where the research was performed. Approval to conduct the study was granted by the Rhodes University
Ethical Standards Committee for Humans prior to the commencement of data collection (Reference number: 2018 Man 01). Permission to collect qualitative data was also requested by sending a formal letter to each formal financial institution. Approval was granted by each institution to conduct the study. The names of participants and their institutions as well as the names of participants are kept anonymous.

\section{Funding Information}

This research did not receive any specific grant from any funding agency in the public, commercial or not-for-profit sectors.

\section{Data availability statement}

The data used for this study were collected by Dr F.T. Asah for his PhD study and are available upon request.

\section{Disclaimer}

The views and opinions expressed in this article are those of the authors and do not necessarily reflect the official policy or position of any affiliated agency of the authors.

\section{References}

Adzido, R.Y.N. \& Azila-Gbettor, E.M., 2014, 'Assessment of supply-side financing of lower-end market SMEs by rural banks in Ghana', Research Journal of Finance and Accounting 5(18), 196-206.

Baby, A. \& Joseph, C.A.C., 2016, 'Bank finance challenges faced by UAE SME sector', Arabian Journal of Business Management Review 1(5), 1-3.

Baltar, F. \& Icart, I.B., 2013, 'Entrepreneurial gain, cultural similarity and transnational entrepreneurship', Global Network 13(2), 200-219. https://doi.org/10.1111/ glob.12020

Bambale, A.J., 2014, 'Research methodological techniques as a model for quantitative studies in social sciences', British Journal of Economics, Management \& Trade 4(1), 862-879. https://doi.org/10.9734/BJEMT/2014/7665

Banking Association of South Africa, 2018, Our industry, viewed 10 November 2018, from http://www.banking.org.za/our_industry/member_banks/member_banks.aspx.

Bartlett, G., Beech, G., De Hart, F., De Jager, P., De Lange, J., Erasmus, P. et al., 2014, Financial management: Turning theory into practice, Oxford University Press, Cape Town.

Bezzina, F. \& Saunders, M.N.K., 2014, 'The pervasiveness and implications of statistical misconceptions among academics with a special interest in business research methods', The Electronic Journal of Business Research Methods 12(2), 29-42.

Brijlal, P., 2013, 'Financial capital and business growth among entrepreneurs in a developing nation, with specific reference to South Africa', Unpublished PhD thesis, University of the Western Cape, Cape Town.

Cenni, S., Monferra, S., Salotti, V., Sangiorgi, M. \& Torluccio, G., 2015, 'Credit rationing and relationship lending: Does firm size matter?', Journal of Banking \& Finance 53(2), 249-265. https://doi.org/10.1016/j.jbankfin.2014.12.010

Collis, J. \& Hussey, R., 2014, Business research: A practical guide for undergraduate and postgraduate students, 4th edn., Palgrave Macmillan, Houndmills, Basingstoke.

Curraj, E., 2017, 'Business digitalization in Albania: Where do SMEs stand?', European Journal of Economics and Business Studies 7(1), 148-152. https://doi.org/10.26417/ ejes.v7i1

Degryse, H., De Goeij, P. \& Kappert, P., 2012, 'The impact of firm and industry characteristics on small firms' capital structure', Small Business Economics 38(4), 431-447. https://doi.org/10.1007/s11187-010-9281-8

De La Torre, A., Peria, M.S.M. \& Schmukler, S., 2008, Bank involvement with SMEs: Beyond relationship lending, viewed 06 May 2018, from http://www. worldbank.org.

Ebrahim, A., Khalil A., Kargbo, M. \& Xiangpei, H., 2016, 'A study of credit risk and commercial banks' performance in Yemen', International Journal of Research 4(1), 57-69. https://doi.org/10.15640/jmpp.v4n1a4

European Commission, 2015, Enterprise and industry, viewed 04 May 2018, from http://ec.europa.eu/enterprise/index-eu.htm.

Fatoki, O., 2014, 'The financing preferences of immigrant small business owners in South Africa', Mediterranean Journal of Social Sciences 5(20), 184-189. https:// doi.org/10.5901/mjss.2014.v5n20p184 
Frelinghaus, A., Mostert, B. \& Firer, C., 2005, 'Capital structure and the firm's life stage', South African Journal of Business Management 36(4), 9-18. https://doi. stage, South African Journal
org/10.4102/sajbm.v36i4.640

Garg, A.K. \& Phayane, N., 2014, 'Impact of small businesses owned by immigrant entrepreneurs on the local community of Brits', Journal of Small Business and Entrepreneurship Development 2(2), 57-85.

Global Entrepreneurship Monitor (GEM), 2014, 2014 report on higher expectation entrepreneurship, viewed 12 April 2018, from www.gemconsortium.org.

Global Entrepreneurship Monitor (GEM), 2017, Entrepreneurial finance, viewed 02 April 2018, from http://www.gem-spain.com/wp-content/uploads/2015/03/ gem-2015-2016-report-on-entrepreneurial-financing.pdf.

Haven, A., 2015, 'The financial system and the financial literacy imperative in developing countries', European Academic Research 3(4), 3754-3779.

Ihuah, P.W. \& Eaton, D., 2013, 'The pragmatic research approach: A framework for sustainable management of public housing estates in Nigeria', Journal of US-China Public Administration 10(10), 933-944.

Ikuomola, A.D. \& Zaaiman, J., 2014, 'We have come to stay and we shall find all means to live and work in this country: Nigerian migrants and life challenges in South Africa', Issues in Ethnology and Anthropology 9(2), 371-389. https://doi. org/10.21301/eap.v9i2.6

IMF (International Monetary Fund), 2016, IMF annual report, viewed 19 March 2018 from https://www.imf.org/external/pubs/ft/ar/2016/eng/pdf/ar16_eng.pdf.

Kapunda, S.M., 2015. Industrial economics and development: An African perspective, Codestria, Dakar.

Konovalova, N., Kristovska, I. \& Kudinska, M., 2016, 'Credit risk management in commercial banks', Polish Journal of Management Studies 13(2), 90-100. https:// doi.org/10.17512/pjms.2016.13.2.09

Kostov, P., Arun, T. \& Annim, S., 2015, 'Access to financial services: The case of the "Mzansi" account in South Africa', Review of Development Finance 5(3), 34-42. https://doi.org/10.1016/j.rdf.2015.04.001

Kraemer-Eis, H., Botsari, A., Gvetadze, S. \& Lang, F., 2018, European Investment Fund (EIF) VC Survey 2018: Fund managers' market sentiment and views on public intervention, EIF Research \& Market Analysis, viewed 23 March 2019, from http:// www.eif.org/news_centre/research/index.htm.

Kumari, A. \& Sita, V., 2010, 'Role of human competencies in human resource management: A study in Indian organisations', International Journal of Sustainable Development 2(3), 29-34.

Kwaning, C.O., Nyantakyi, K. \& Kyereh, B., 2015, 'The challenges behind SMEs' access to debts financing in the Ghanaian financial market', International Journal of Small Business and Entrepreneurship Research 3(2), 16-30.

Liang, L.W., Huang, Y., Liao, C.F. \& Gao, Y.T., 2017, 'The impact of SMEs' lending and credit guarantee on bank efficiency in South Korea', Review of Development Finance 7(1), 134-141. https://doi.org/10.1016/j.rdf.2017.04.003

Makomeke, P.C., Makomeke, C. \& Chitura, M., 2016, 'The effectiveness of commercial banks' credit appraisal techniques in improving asset quality', Journal of Economics and Finance 7(5), 63-78. https://doi.org/10.9790/5933-0705016378

Menike, L.M.C.S., 2015, 'Capital structure and financing of small and medium sized enterprises: Empirical evidence from a Sri Lankan survey', Journal of Small Business and Entrepreneurship Development 3(1), 54-65. https://doi.org/10.15640/jsbed.v3n1a6

Mills, K.G., 2014, The state of small business lending: Credit access during the recovery and how technology may change the game, Working paper, Harvard Business School, Cambridge, MA.

Mutoko, W.R., 2015, 'Challenges of financing small, medium and microenterprises: The case of Botswana manufacturing sector', Journal of Business and Management Dynamics 5(1), 1-7. https://doi.org/10.4102/jbmd.v5i1.17

Narh, P., 2013, Philosophical foundation of knowledge creation on Africa: Farafina Institute's discussion papers series, viewed 08 April 2018, from http://www. farafina-institute.org/attachments/article/119/Philosophical\%20foundation\%20 of $\% 20$ knowledge\% 20 creation $\% 20$ on\%20Africa.pdf.

Nieman, G.H. \& Nieuwenhuizen, C., 2014, Entrepreneurship: A South African perspective, Van Schaik, Pretoria.

NPC (National Planning Commission), 2015, Our future-make it work; National Development Plan 2030, viewed 16 July 2018, from http://www.poa.gov.za.
Organisation of Economic Cooperation and Development (OECD), 2015, Unlocking SME finance through market based debt, OECD Publishing, Paris, viewed 23 February 2017, from http://www.oecd.org/finance/Unlocking-SME-finance23 February 2017, from http:///

Organisation of Economic Cooperation and Development (OECD), 2017, African Economic Outlook 2017: Regional development and spatial inclusion, OECD Publishing, Paris, viewed 23 June 2018, from https://www.oecd.org/eco/ surveys/2017-OECD-Economic-Survey-South-Africa-overview-2017.pdf.

Padachi, K., Howorth, C. \& Narasimhan, M.S., 2012, 'Working capital financing preferences: The case of Mauritian manufacturing SMEs', Asian Academy of Management Journal of Accounting and Finance 8(1), 125-157.

Padilla-Perez, R. \& Ontanon, R.F., 2013, 'Commercial bank financing for microenterprises and SMEs in Mexico', Cepal Review 11(10), 7-21. https://doi. org/10.18356/4705ad8f-en

Pai, V.S. \& Hiremath, C.V., 2013, 'Comparative performance of domestic and foreign owned firms: Evidence from an emerging market', Review of Integrative Business and Economic Research 2(2), 416-433.

Panda, B. \& Leepsa, N.M., 2017, 'Agency theory: Review of theory and evidence on problems and perspectives', Indian Journal of Corporate Governance 10(1) 74-95. https://doi.org/10.1177/0974686217701467

Peprah, J.A., Mensah, A.O. \& Akosah, N.B., 2016, 'Accessibility to public procurement: SMEs entity perspective in Ghana', European Journal of Business and Social Sciences 4(2), 25-40.

Quartey, P., Turkson, E., Abor, J.A. \& Iddrisu, A.M., 2017, 'Financing the growth of SMEs in Africa: What are the constraints to SME financing within ECOWAS?', Review of Development Finance 7(3), 8-28. https://doi.org/10.1016/j.rdf. 2017.03.001

Rahman, M.M., Zheng, C. \& Ashraf, B.N., 2015, 'Bank size, risk-taking and capital regulation in Bangladesh', Eurasian Journal of Business and Economics 8(15), 95-114. https://doi.org/10.17015/ejbe.2015.015.05

Ramlee, S. \& Berma, B., 2013, 'Financing gap in Malaysian SMEs: A supply-side perspective', South African Journal of Economic and Management Sciences 1(16), 115-126. https://doi.org/10.4102/sajems.v16i5.641

Richard, E.M. \& Mori, N.G., 2012, 'SMEs access to financial services: Bankers' eye', Chinese Business Review 11(2), 217-223. https://doi.org/10.17265/1537$1506 / 2012.02 .008$

Siddik, N.A., Kabiraj, S. \& Joghee, S., 2017, 'Impacts of capital structure on performance of banks in a developing economy: Evidence from Bangladesh', International Journal of Financial Studies 5(13), 2-18. https://doi.org/ $10.3390 /$ ijfs5020013

Stoop, P.N. \& Churr, C., 2013, 'Unpacking the right to plain and understandable language in the Consumer Protection Act 68 of 2008', Potchefstroom Electronic Law Journal 16(5), 514-553. https://doi.org/10.4314/pelj.v16i5.12

Taneli, M. \& Ohl, B., 2014, 'Information acquisition and learning from prices over the business cycle', Journal of Economic Theory 15(8), 585-633. https://doi. org/10.1016/j.jet.2015.03.013

Terre Blanche, M., Durrheim, K. \& Kelly, K., 2006, 'First steps in qualitative data analysis', in M. Terre Blanche, K. Durrheim \& D. Painter (eds.), Research in practice. Applied methods for the social sciences, University of Cape Town Press, Cape Town.

Testa, S. \& Frascheri, S., 2015, 'Learning by failing: What we can learn from unsuccessful entrepreneurship education', The International Journal of Management Education 13(1), 11-22. https://doi.org/10.1016/j.ijme.2014.11.001

United Nations Development Programme (UNDP), 2016, African Economic Outlook 2016: Regional development and spatial inclusion, OECD Publishing, Paris, viewed 27 June 2018, from http://dx.doi.org/10.1787/aeo-2015-en.

United Nations, 2015, Transforming our world: The 2030 agenda for sustainable development, United Nations, New York, viewed 27 September 2018, from https://sustanabledevelopment.un.org/content/documents/21252030.

World Bank, 2015, GINI Index estimates, viewed 27 June 2018, from http://data. worldbank.org/indicator/SI.POV.GINI?page=1.

World Investment Report, 2017, Investment and the digital economy, viewed 12 April 2018, from https://unctad.org/en/PublicationsLibrary/wir2017en.pdf. 